УДК $811.111-26$

DOI: $10.31891 / 2415-7929-2019-19-9$

SADOVETS O., ORLOVSKA O.

Khmelnytskyi National University

\title{
TEXTUALITY STANDARDS AS A BASIS FOR LINGUISTIC ANALYSIS OF ENGLISH LANGUAGE TEXTS
}

The paper deals with the issue of linguistic analysis of English language texts on the basis of textuality standards which allow to carry out a complete analysis of the text and judge about its communicative value. The appropriateness of linguistic analysis of texts with the consideration of seven standards of textuality have been substantiated. These standards are: coherence (introduction of a new item in the text and subsequent referral to it by means of another item), cohesion (the ways in which components of the sentences in a text are mutually connected grammatically and lexically), intentionality and acceptability (a speaker/author's intention to produce a sound piece of information and the recipient's desire to accept the text as a communicative piece of information), informativity (ways and means by which parts of the text acquire communicative value), contextuality (focusing on the context and the role it plays in any form of communication) and intertextuality (understanding and perception of one text on the basis of the structure of another text similar to it). Special attention has been paid to cohesion as semantic relation between elements of the text. Categories of cohesion such as reference, substitution, ellipsis, conjunction and lexical cohesion have been analyzed. It has been defined that the linguistic analysis carried out with consideration of seven standards of textuality requires knowledge of different branches of linguistics - syntax, morphology, phonology, grammar, semantics, lexicology, stylistics, pragmatics, sociolinguistics. Definite examples of every standard application have been presented. It has been substantiated that the appropriateness of a text is the agreement between its setting and the ways in which the standards of textuality are applied. The standards of textuality entail factors of cognition, planning and social environment merely to distinguish what constitutes a text. Keywords: textuality, linguistic analysis, English language text, linguistics, textuality standards, communicative value.

САДОВЕЦЬ О. В., ОРЛОВСЬКА О. В. Хмельницький національний університет

\section{СТАНДАРТИ ТЕКСТУАЛЬНОСТІ ЯК ОСНОВА ЛІНГВІСТИЧНОГО АНАЛІЗУ АНГЛОМОВНИХ ТЕКСТІВ}

у статті висвітлено питання здійснення лінгвістичного аналізу англомовних текстів з використанням стандартів текстуальності як основи для повної характеристики текстів, аналізу їх комунікативної мети. Обґрунтовано важливість та доцільність лінгвістичного аналізу текстів з урахуванням семи стандартів текстуальності: послідовності (логічності, узгодженості), зв'язності (когезії), наміру (цілеспрямованості), сприйняття, інформативності, контекстуальності, інтертекстуальності. З'ясовано, що такий аналіз вимагає знання різних галузей лінгвістики - синтаксису, морфології, фонології, граматики, семантики, лексикології, стилістики, прагматики, соціолінгвістики тощо. Наведено конкретні приклади для демонстрації практичного застосування кожного стандарту.

Ключові слова: текстуальність, лінгвістичний аналіз, англомовний текст, лінгвістика, стандарти текстуальності, комунікативна спрямованість.

Relevance of the study. Functional and semantic approach to text analysis offers substantially broader insight into the definition of a text message content and considers a text as a subject of the study. Such approach presupposes that the most effective way of information analysis is the analysis of the complete texts. For the first time it was seriously considered in the $60-70$ s of the $20^{\text {th }}$ century when a new branch of linguistics was singled out text linguistics which was aimed at studying the peculiarities of information organization within the sentences and between them, analyzing their consistence (coherence), connection (cohesion), thematic and structural organization. But at that time linguists didn't have the purpose of changing traditional linguistics. They were aimed at broadening the limits of scientific description of linguistic phenomena. Nevertheless, they happened to go beyond the limits of sentence analysis and opened a broader spectrum of content connections and speech structuring.

It is considered that the emergence of text linguistics as a separate scientific branch is substantiated by inner (linguistic) peculiarities of the text and external (extra linguistic) ones. Substantiating the necessity of singling out text linguistics as a separate discipline linguists assert that the main reason of its emergence is the necessity of logical explanation of some linguistic phenomena, which is impossible to do using traditional definitions based exclusively on the analysis of sentences. It is especially urgent for English. Primarily we have in mind such widely spread phenomena as prominalization in all its dimensions, the use of articles, choice of tense forms and their relations etc. Text linguistics as a separate scientific discipline is substantiated by extra linguistic factors, namely the external influence of other scientific disciplines directly adjacent to language studies - literature, psychology, sociology etc.

Theoretical framework. A considerable number of scientists and linguists study peculiarities of text linguistics and carry out researches in this branch, namely those that are directly related to linguistic analysis of English language texts. Among them are M. Bloor [1], C. Coffin [1], P. Crane [3], J. Donohue [2], S. Eggins [4], P. Grice [5], E. Hatch [6], D. Morley [8], H. Widdowson [10] and others. In this respect special attention should be given to works of the above mentioned linguists related to standards of textuality and their role in multifaceted 
linguistic analysis of texts. The majority of linguists agree that a text is defined as a communicative situation that corresponds to some definite textuality standards. These standards include a complex set of features that texts must possess to be called communicative. If at least one of these standards is not adhered to, the text cannot be called communicative. Taking into account the importance of these standards and their role in the formation of communicative texts we consider it necessary to outline the essence and peculiarities of using each of these standards for linguistic analysis of texts.

The aim of the paper. The aim of the paper is the substantial analysis of textuality standards in relation to English texts, defining the essence and significance of each standard for performing linguistic analysis of texts and giving definite examples to demonstrate their practical application.

Results. In the process of scientific and linguistic study it was determined that complete linguistic analysis of English language texts must be carried out with consideration of seven standards of textuality: consistency (coherence); connection (cohesion); aim (intentionality); acceptability; informativity; contextuality; intertextuality. It is essential to consider each standard in detail.

Cohesion describes the ways of interrelation (grammar and lexical) between components. Cohesion takes place where interpretation of any element in discourse requires reference to another element of discourse. Relations are made between one sentence and another, as the understanding of one sentence depends on some other element of another sentence, usually a previous one. Cohesion is a meaningful relationship between two elements in the text, and one of these elements is crucial for the definition of the other one. This other element can also be found in the text but its location is in no way determined by the grammatical structure [1, p. 39].

The notion of cohesion is key for providing meaningful relations due to which any excerpt of discourse or a written text can function as a text and this notion is systematized with the help of five different categories providing practical means for the description and analysis of texts. Each of these categories is represented in the text with special devices - repetitions, omissions, the use of specific words and constructions, which signal that the interpretation of some part of the text depends on other elements of the text. These categories include reference, substitution, ellipsis, conjunction, and lexical cohesion [2, p. 123].

Reference as a cohesive device is related to introduction of a new element into the text with further reference to it by means of another element which, as a rule, is shorter in its form. In this respect, demonstrative pronouns, comparative structures, different lexical constructions, even adjectives and adverbs are used. The effect of reference is in the search of information (referential meaning) from another place in the sentence or in a neighboring sentence with the help of one of the grammatical devices mentioned above. Cohesion means the stability of reference due to which the same element appears in speech again and again [3, p. 143].

Substitution is generally used instead of another word or phrase to avoid repetition. It also helps to shorten the text. There are different types of substitution, such as nominal (Others are predators...), verbal and clausal (... and to do so with minimum expenses we need...).

In the course of ellipsis, elements of the text are physically removed because the author is convinced that the readers will insert the missing elements by themselves. In this case it is for the reader or listener to make cohesive connections. As in the case of substitution, there are three types of ellipsis - nominal, verbal and clausal.

Conjunction presupposes the use of connectives and adverbs to connect neighboring sentences according to some meaningful relations. Conjunctions can be roughly divided into: additive (in addition...etc.), adversative (however...etc.), causal (as a consequence...etc.) and temporal (once...etc.). Conjunction elements serve to intensify and highlight the connection between other elements of the text. A definite choice of a conjunctive marker gives a reader a hint about the way the author wants the reader to perceive the utterance so that he/she can understand the text [4, p. 243-247].

Finally, lexical cohesion concerns meaningful connections, such as repetition, synonymy, taxonomy, reformulation (anaphoric nouns) etc., made by definite lexical elements. The knowledge of meaningful structures is necessary to understand this type of cohesion.

Consistency (coherence) is the main component of any form of linguistic analysis of texts because if the text is not fully understood we cannot talk about its communicative value. The aim and goals of text linguistics research determine the conditions according to which some texts are acceptable and others are not. It is quite difficult to determine what makes a text coherent. Coherent texts must have logical structure to make the reader perceive the text as a whole unit that has sense and is not a random set of sentences. Consistency is something that gives a text some meaning (semantic, contextual) that corresponds to our expectations of the text. In general, a logical and coherent text must have a strict structure: situation - problem - solution - evaluation. According to this structure the set of sentences: I defeated my enemy. I shot at him. I was on guard duty. I saw an enemy soldier must have a logical structure like this: I was on guard duty. I saw an enemy soldier. I shot at him. I defeated my enemy [5, p. 262-263].

Intentionality and acceptability are considered to be a pair standard. In any text an author has an intention to create a sound informational message for the recipient. Recipients in their turn must be ready and have intention to accept the text as a communicative message. To do this, the author and the recipient must follow the principle of pragmatic cooperation the essence of which is that every person must make all the efforts to provide successful intentional communication. Textuality depends on knowledge of pragmatic principles. Intentionality and acceptability are based on Paul Grice's principles of cooperation (“...communication must take place when it is 
necessary, the way it is necessary, correspond to the set aim or theme of communication" [6]). For example, when a recipient is addressed as "Well, where do which part of the town do you live into?", he/she understands that the person who is uttering this phrase doesn't speak English well enough and makes grammar mistakes. But the recipient that is aimed at cooperation ignores these mistakes, doesn't stress them because anyway they let him/her understand the essence of the message [6].

Informativity deals with the ways parts of the text acquire communicative value. Informativity provides the ease and correctness of information perception, allows to avoid misunderstandings and ambiguity. For example, on the construction ground where a new residential area was being built an announcement was placed: Call us before you dig. You may not be able to afterwards. Such a message is not quite informative as we don't really understand its essence - why we won't be able to call afterwards. As it appears, a telephone cord was placed there and if damaged people wouldn't be able to use the phone.

Sometimes to avoid repetition demonstrative pronouns are used instead of nouns, which can cause the loss of informativity. That's why when the question is whether to use pronoun to avoid repetition or use the word twice for providing better informativity, the latter is preferable [7].

Contextuality takes into account the role that context plays in any form of communication. Every text, either oral or written, takes place in some context. Actually, it means that in any communicative situation quality and results of communication are determined by participants' context knowledge. This aspect of language use is studied by pragmatics and sociolinguistics. Pragmatics focuses on what the participants in a discourse intend to accomplish by means of the use of the language (what speech act is performed in some situation) and sociolinguistics is aimed at defining the role that knowledge of the participants plays in a successful communicative situation [8].

For example, the phrase SLOW CHILDREN AT PLAY can be understood in two different ways depending on the situation in which it is used (as a road sign and as a text about children who have some mental or physical problems). It is the context that gives possibility to choose the correct understanding of ambivalent messages.

One more example is a notice "Do not move!" To understand it correctly you should know the context of its use (place). It can be found in the X-ray room as the main instruction to those undergoing the procedure or on the entrance to some military post.

Intertextuality is the least linguistic principle out of all the principles of textuality. It is as a rule related to the study of literature, publicist materials, general knowledge and literally it means that the formation and understanding of one text is influenced by the structure of another text, which is similar to a given one. For example, the correct reading and perception of poetry is possible only if you read poetry before. The same concerns newspaper language (e.g. simplified grammar forms in headlines, which to an inexperienced reader will look like mistakes made by the author), proverbs and sayings which cannot be perceived literally etc.

The text SLOW CHILDREN AT PLAY can be correctly understood only by people who live in the city, drive and know that this is a notice explaining the road sign demanding to reduce speed in the residential area where children play $[9$, p. $39 ; 10$, p. 243-246].

To understand the phrase «I hate all these ketchups. I can only eat Uncle Ben ketchups», a person must know that Uncle Ben is not a relative of the speaker but a brand of sauces and ketchups.

Conclusions. Thus, it is quite clear that very diverse knowledge of general and applied linguistics is involved in the description of texts. For instance, study of cohesion presupposes some knowledge of syntax, semantics (sometimes even morphology and phonology), whereas intentionality and acceptability cannot be perceived without serious knowledge of pragmatics. Contextuality significantly depends on knowledge of sociolinguistics and pragmatics while intertextuality depends on the recipient's previous experience and knowledge of such texts (literary and publicist). At the same time, psycholinguistics is necessary to understand the communicative value of some texts.

In the result of the research carried out in the paper we can make a conclusion that textuality standards are important for multifaceted linguistic analysis of texts; they give possibility to analyze texts not only in terms of linguistics but adjacent branches - sociolinguistics, pragmatics etc. Text analysis performed with consideration of textuality standards encompasses all aspects of text analysis - from the simplest grammar phenomena to extra linguistic factors, which impact the general perception of the text.

Prospects of further research. The results of the conducted research can be used in theory and practice of linguistic analysis of texts taken from different branches of science. Nevertheless, further detailed research should be carried out to study peculiarities of textuality standards application for the analysis of texts for specific purposes.

\section{References}

1. Bloor M., Bloor T. The Practice of Critical Discourse Analysis. London : Hodder Arnold, 2007. 207 p.

2. Coffin C., Donohue J., North S. Exploring English Grammar: From Formal to Functional. London : Routledge, 2009.464 p.

3. Crane P. Texture in Text: A Discourse Analysis of a News Article Using Halliday and Hasan's Model of Cohesion. Nagoya University of Foreign Studies. 2006. Volume 30. P.131-156. URL:. http://library.nakanishi.ac.jp/kiyou/gaidai(30)/08.pdf (accessed 15 Oct. 2020).

4. Eggins S. An Introduction to Systemic Functional Linguistics. Applied Linguistics. Volume 17. Issue 2, June 1996. P. $262-263$.

5. Grice's cooperative principles. Lancaster University, 2018. URL: https:/www.lancaster.ac.uk/fass/projects/stylistics/topic12/ 14cp1.htm (accessed 17 Oct. 2020). 
6. Hatch E. Discourse and Language Education. Cambridge. New York : Cambridge University Press, 1992. 333 p.

7. Literary Terms. 2015. URL: https://literaryterms.net/. (accessed 10 Sep. 2020).

8. Morley D. Explorations in Functional Syntax: A New Framework for Lexicogrammatical Analysis. London : David Brown Book Company, 2004. $224 \mathrm{p}$.

9. Textuality: Definition \& Standards. 2014. URL: https://study.com/academy/lesson/textuality-definition-standards.html. (accessed 04.09.2020).

10. Widdowson, H. G. Discourse Analysis. Oxford \& New York : Oxford University Press. 2007. 133 p.

Надійшла / Paper received: 05.10.2020

Надрукована / Paper Printed : 04.11.2020 